\title{
OS "HERMENEUTAS DOS GRAMPOS": UMA DISFUNCIONALIDADE EPISTÊMICA
}

\author{
${ }^{1}$ Antonio Eduardo Ramires Santoro \\ ${ }^{2}$ Francisco Ramalho Ortigão Farias
}

\begin{abstract}
RESUMO
A interceptação das comunicações telefônicas é meio de obtenção de prova que vem sendo aplicada em casos de grande repercussão pública e gerando muitas polêmicas, como a realização de interpretações das conversas por parte dos agentes policiais, que terminam por conduzir o convencimento judicial com a atribuição de significados ocultos aos termos usados pelos interlocutores. $\mathrm{O}$ objeto deste trabalho é perquirir a legitimidade para valorar o conteúdo das conversas monitoradas e a validade das decisões proferidas com base nas interpretações prejudiciais diante do princípio da imparcialidade e do modelo epistêmico de conhecimento que é o processo.
\end{abstract}

Palavras-chave: Interceptação telefônica, Imparcialidade, Modelo epistêmico, Verdade, Valoração da prova

\section{LOS HERMENEUTAS DOS GRAMPOS: UNA ANOMALÍA EPISTÉMICA}

\section{RESUMEN}

La intervención de las comunicaciones telefónicas es una medida de investigación que se ha aplicado en casos de gran atención pública y con muchas controversias, como, por ejemplo, las interpretaciones policiales de las conversaciones, que en última instancia conduce la convicción judicial asignando significados ocultos a los términos utilizados por las personas investigadas. El objeto de este trabajo es investigar la legitimidad para hacer la valoración del contenido de las conversaciones y la validez de los juicios basados en las interpretaciones policiales preliminares bajo el principio de imparcialidad y el modelo epistémico del conocimiento que es el proceso.

Palabras-claves: Intervención telefónica, Imparcialidad, Modelo epistémico, Verdad, Valoración de la prueba

1 Professor Adjunto de Direito Processual Penal da Universidade Federal do Rio de Janeiro - UFRJ, Rio de Janeiro (Brasil). Pós-doutor pela Universidad Nacional de La Matanza - UNLaM, Buenos Aires (Argentina). Doutor e Mestre pela Universidade Federal do Rio de Janeiro - UFRJ, Rio de Janeiro (Brasil). E-mail: antoniosantoro@direito.ufri.br

2 Professor de Prática Penal e Coordenador do Núcleo de Prática Jurídica da Universidade Federal do Rio de JaneiroFND/UFRJ, Rio de Janeiro (Brasil) ; Doutorando pela Universidade Federal Fluminense - UFF, Rio de Janeiro (Brasil).

E-mail: franciscoortigao@uol.com.br 


\section{INTRODUÇÃO}

Em 1996 entrou em vigor a Lei $n^{\circ} 9.296$ que regulou a parte final do artigo $5^{\circ}$, inciso XII da Constituição, dispondo regras sobre a interceptação das comunicações telefônicas e telemáticas, medida que se tornou, 10 (anos) depois e sobretudo com o advento dos avanços tecnológicos comunicacionais, em uma das maiores panaceias para o suposto conhecimento da verdade no processo penal.

Essas medidas têm por característica alijar a defesa da participação dialética na produção da prova, vez que são determinadas pelo magistrado, de ofício ou a requerimento da autoridade policial ou do ministério público, são executadas pelos investigadores com participação direta e efetiva das operadoras de telefonia com a utilização de sistemas de tecnologia da informação especialmente desenvolvidos para realizar a escuta e o armazenamento de áudios ${ }^{1}$, implicam em um monitoramento comumente por longo tempo (meses ou até anos) em que o cidadão é vigiado à sorrelfa, sem qualquer oportunidade de exercer o comezinho (porém fundamental) direito de não se autoincriminar, com a submissão de todos os dados ao conhecimento do juiz que deferiu e prorrogou a medida, lamentavelmente o mesmo juiz que irá julgar a ação penal condenatória eventualmente proposta em face do investigado, que não tem oportunidade de exercer o contraditório direto.

Assim, em que pese ter essa medida nascido da relativização constitucionalmente admitida do direito fundamental ao sigilo das comunicações, da intimidade e da privacidade,

\footnotetext{
${ }^{1}$ Pelo que se tem notícia, há no Brasil basicamente três sistemas de TI utilizados para recepção e armazenamento Dados colhidos do Processo $\mathrm{n}^{\mathrm{o}}$ 0.00.000.001328/2012-95, que tramitou junto ao Conselho Nacional do Ministério Público e se tratava de um Pedido de Providência formulado pelo Conselho Federal da Ordem dos Advogados do Brasil, consistente no requerimento de auditoria e inspeção nos sistemas de escuta e monitoramento de interceptações telefônicas utilizados pelas unidades do ministério público brasileiro ${ }^{1}$, mostram que, a partir das consultas feitas às 30 unidades do ministério público brasileiro, 8 (oito) adquiriram o Sistema Guardião (o ministério público federal e o ministério público dos estados de Goiás, Mato Grosso, Rio Grande do Norte, Rio Grande do Sul, São Paulo, Santa Catarina e o Distrito Federal); 6 (seis) adquiriram o Sistema Wytron (o ministério público dos estados de Alagoas, Amapá, Ceará, Maranhão, Pará e Rondônia); 3 (três) adquiriram o Sistema Sombra (o ministério público dos estados da Bahia, Mato Grosso do Sul e Paraíba); 4 (quatro) utilizam o Sistema Guardião disponibilizado ou cedido por órgãos do Poder Executivo (o ministério público dos estados do Espírito Santo, Minas Gerais, Amazonas e Tocantins); 9 (nove) não possuem ou não têm acesso a qualquer um desses sistemas (o ministério público militar, o ministério público do trabalho e o ministério público dos estados de Sergipe, Pernambuco, Acre, Paraná, Piauí, Roraima e Rio de Janeiro).

Portanto, das 30 (trinta) unidades do ministério público, 21 (vinte e uma) adquiriram ou utilizam sistemas de TI que se destinam a receber e armazenar dados obtidos de interceptações telefônicas ou de dados. Destas 21 (vinte e uma) unidades que operam sistemas de monitoramento de comunicações, 12 (doze) "não dispõem de ato normativo versando sobre procedimentos e rotinas adotadas" " e 18 (dezoito) recorrem a policiais civis e/ou militares na operação.

Quanto à aquisição desses sistemas pelos Departamentos de Polícia Federal dos Estados não há dados tão precisos quanto esses constantes do processo que tramitou no Conselho Nacional do Ministério Público, mas dados do Portal da Transparência do governo federal demonstram que as empresas Dígitro Tecnologia Ltda., Federal Tecnologia de Software Ltda.-EPP e Wytron Technology Corp. Ltda. comercializaram com o Departamento de Polícia Federal, sendo, ademais, amplamente divulgada a contratação do Sistema Guardião pelas Superintendências da Polícia Federal de Santa Catarina, Paraná, São Paulo e Rio de Janeiro.
} 
não se deve ignorar a existência de conflitos com os direitos de estatura constitucional ao contraditório e à ampla defesa, já que se trata do que Geraldo Prado chamou de método oculto de investigação ${ }^{2}$, inviabilizando a participação de quem está sendo monitorado, bem como do direito ao silêncio e, mais amplamente, o direito de não produzir provas contra si mesmo, posto não ser dada opção ao investigado de falar ou calar-se enquanto conversa (e eventualmente confessa) sobre o ato que possa ter praticado preteritamente. Essas incompatibilidades são geralmente ignoradas nos casos concretos pela jurisprudência brasileira.

Há que se ter em vista que a prática da interceptação telefônica nesses quase 20 (vinte) anos de vigência da Lei $n^{0}$ 9.296/96 desvelou usos conflituosos com os direitos fundamentais, que vão além das vulnerações ínsitas à própria natureza da medida anteriormente citadas.

Isso pode se dar por uma regulação legal equivocada, omissa ou dúbia.

É uma regulação legal equivocada, por exemplo, a regra de determinação da competência pela prevenção inserta no artigo $1^{\circ}$ da Lei $n^{\circ} 9.296 / 96$, em que o magistrado que defere e acompanha a execução da medida e, portanto, toma conhecimento do conteúdo das conversas interceptadas sem qualquer participação da defesa, vai julgar a ação penal proposta, violando o princípio da imparcialidade da jurisdição ${ }^{3}$.

Há clara omissão proposital na Lei $n^{0} 9.296 / 96$, precisamente no seu artigo $5^{\circ}$, ao deixar para o juiz definir "a forma de execução da diligência" em sua decisão que a defere, em vez de dispor expressamente sobre o assunto.

O mesmo artigo $5^{\circ}$ contém uma dubiedade que até hoje cobra o seu preço. Trata-se da péssima definição do prazo máximo de duração da medida que, na falta de uma vírgula esclarecedora ${ }^{4}$, deixou para a jurisprudência estabelecer o tempo durante o qual o cidadão pode ficar sendo vigiado pelas agências de persecução penal.

\footnotetext{
${ }^{2}$ PRADO, Geraldo. Prova penal e sistema de controles epistêmicos: a quebra da cadeia de custódia das provas obtidas por métodos ocultos. São Paulo: Marcial Pons, 2014, p. 78.

${ }^{3}$ MAYA, André Machado. Imparcialidade e processo penal: da prevenção da competência ao juiz das garantias. Rio de Janeiro: Lumen Juris, 2011, trata da questão da prevenção como critério positivo de competência, em clara oposição ao direito à imparcialidade, realizando uma ampla leitura das decisões do Tribunal Europeu de Direitos Humanos; GUERRERO PALOMARES, Salvador. La Imparcialidad Objetiva del Juez Penal: Análisis jurisprudencial y valoración crítica. Pamplona: Aranzadi, 2009, faz uma ampla análise das decisões dos Tribunais Espanhóis e do Tribunal Europeu de Direitos Humanos sobre a violação da imparcialidade objetiva, verificável conforme o caso concreto conforme o conteúdo das decisões proferidas antes ${ }_{4}$ da propositura da ação penal. Ambos os trabalhos são extremamente valiosos para o contexto deste trabalho.
}

dispositivo sem uma vírgula esclarecedora. Veja-se a redação da Lei:

O legislador ordinário foi gramaticalmente infeliz na redação do artigo $5^{\circ}$ da Lei 9.296/96. Redigiu o 
Diante da subversão prática da interceptação telefônica de meio de obtenção de prova em estado de vigilância (sendo mesmo chamado em casos concretos de monitoramento ou acompanhamento telefônico e lacanianamente revelando a natureza do seu uso), a jurisprudência dos tribunais superiores foi obrigada a se pronunciar sobre medidas que duraram meses ou anos.

O Supremo Tribunal Federal definiu, no julgamento do Habeas Corpus 83.515, de relatoria do Ministro Nelson Jobim, no dia 16 de setembro de 2004, por maioria, que eram válidas as diligências de interceptação telefônica que, com as renovações, duraram 7 (sete) meses.

Ocorre que em 09 de setembro de 2008, a Sexta Turma do Superior Tribunal de Justiça, sob a relatoria do Ministro Nilson Naves, adotou posição diversa ao julgar o Habeas Corpus 76.686 e definir que não era possível renovar ilimitadamente as autorizações de interceptação das comunicações. Dessa decisão foi interposto o Recurso Extraordinário 625.263, o qual foi distribuído para relatoria do Ministro Gilmar Mendes.

A importância da distribuição deste recurso para o Ministro Gilmar Mendes é mais profunda do que se poderia, a princípio, imaginar. Isso porque no dia 20 de novembro de 2008 (onze dias depois do julgamento proferido pela Sexta Turma do Superior Tribunal de Justiça em sentido oposto ao entendimento dominante no Supremo Tribunal Federal), a sessão Plenária do Supremo decidiu sobre o recebimento da denúncia no Inq 2424, conhecida como “Operação Furacão”, que terminou por levar preventivamente à prisão empresários, bicheiros, desembargadores federais e até um Ministro do Superior Tribunal de Justiça.

Um dos espinhosos temas que foram tratados nesse julgamento era sobre a legalidade das diversas prorrogações da medida de interceptação telefônica proferidas pelo Ministro

\footnotetext{
“Art. 5 A decisão será fundamentada, sob pena de nulidade, indicando também a forma de execução da diligência que não poderá exceder o prazo de 15 (quinze) dias, renovável por igual tempo uma vez comprovada a indispensabilidade do meio de prova."

Observe que uma vírgula colocada antes da expressão "uma vez", tornaria essa expressão uma locução conjuntiva subordinativa condicional, com o mesmo sentido de "se" ou "caso" e não limitaria expressamente a prorrogação a apenas uma única vez. Veja-se que o trecho em comento teria a seguinte redação “...não poderá exceder o prazo de 15 (quinze) dias, renovável por igual tempo, uma vez comprovada a indispensabilidade do meio de prova."

De outro lado, se existisse uma vírgula depois da expressão "uma vez" estaríamos diante de um adjunto adverbial de intensidade que modifica o adjetivo "renovável" e, portanto, indicaria que só é possível renovar a diligência uma única vez, como se pode ver pela redação modificada do trecho “...não poderá exceder o prazo de 15 (quinze) dias, renovável por igual tempo uma vez, comprovada a indispensabilidade do meio de prova." Todavia, essa vírgula não existe.
} 
Cezar Peluso. Por maioria e algum desconforto com alguns votos ${ }^{5}$, foi decidido que as prorrogações eram válidas, mas o Ministro Gilmar Mendes afirmou expressamente:

\begin{abstract}
Sem me comprometer - tenho impressão de que vamos nos deparar com outros casos e já me abalanço a pensar em proporcionalidade para, eventualmente, fixar limites temporais em relação a isso -, é preciso deixar bem claro que até mesmo as prorrogações precisam ser especificamente fundamentadas. ${ }^{6}$
\end{abstract}

Naturalmente a oportunidade para rever sua posição está no citado Recurso Extraordinário 625.263, cuja Repercussão Geral foi admitida pelo Plenário Virtual do Supremo Tribunal Federal em 13 de junho de 2013.

No entanto, é importante ressaltar que antes do julgamento do recebimento da denúncia no Inq 2424 (“Operação Furacão"), o Ministro Gilmar não expunha em suas decisões qualquer dúvida em acolher a tese da possibilidade das prorrogações sucessivas das medidas de interceptação telefônica, cabendo perquirir o que o teria feito admitir poder mudar de opinião.

Ao assumir a Presidência do Supremo Tribunal Federal em abril de 2008, o Ministro Gilmar Mendes concedeu uma entrevista à Revista Veja (edição de 19 de abril de 2008) em que, ao ser perguntado sobre a apuração da "CPI dos Grampos" de que existiriam naquele momento mais de 500.000 (quinhentas mil) "escutas telefônicas" autorizadas pela Justiça no país, respondeu o seguinte:

Os juízes devem ter mais cuidado em relação a isso. A lei prevê que o prazo para uma interceptação telefônica é de quinze dias. Mas o entendimento dos juízes é que esses quinze dias podem ser renovados de maneira ilimitada. O resultado é que hoje

\footnotetext{
${ }^{5}$ O Ministro Marco Aurélio votou pela invalidade das prorrogações reiteradas, como já havia feito nas outras oportunidades. A Ministra Carmen Lúcia acompanhou o voto condutor, mas ressalvou que não entendia ser possível a prorrogação das autorizações, e sim uma "nova ordem de interceptação" com base em fatos novos. O Ministro Lewandowski entendeu ser possível a renovação em caso de "crimes de natureza permanente (...) ou crimes complexos". O Ministro Eros Grau afirmou que "se (...) pensar nas garantias que esta Corte deve tornar positivas em relação a cada indivíduo (...) acompanho a exposição do Ministro Marco Aurélio", mas "neste caso (...) não tenho dúvidas em acompanhar o relator". O Ministro Carlos Britto votou na mesma linha da Ministra Carmen Lúcia. A Ministra Ellen Gracie votou com o relator. O Ministro Celso de Mello votou com o relator, ressalvando sua preocupação na mesma forma do entendimento do Ministro Marco Aurélio, que ironizou o voto proferido:

"O SENHOR MINISTRO CELSO DE MELLO: Peco vênia, Senhor Presidente, na linha de precedente firmado pelo Plenário do Supremo Tribunal Federal (HC 83.515/RS, Rel. Min. NELSON JOBIM), notadamente sobre a questão pertinente à prorrogação do prazo de autorização para interceptação telefônica (Lei $n^{o}$ 9.296/96, art. $5^{\circ}$ ), para acompanhar o eminente Relator, não obstante partilhe -como o fazem os demais Juizes desta Suprema Corte - das preocupações reveladas pelo Ministro MARCO AURÉLIO.

O SENHOR MINISTRO MARCO AURÉLIO - Mas, para este caso, as preocupações não valem." (grifos no original)

6 Inteiro teor do Acórdão. Inq 2424/RJ. STF. Pleno. $\quad$ Disponível em <http://redir.stf.jus.br/paginadorpub/paginador.jsp?docTP=AC\&docID=609608> . Acesso em 13 de marco de 2015 .
} 
existem escutas instaladas há dois ou três anos em um mesmo telefone. Esses procedimentos precisam ser revistos. Outra questão delicada é a divulgação desse conteúdo por agentes policiais antes mesmo de o juiz ser informado sobre ele. Não temos hoje mecanismos para coibir isso. É notória a participação dos agentes policiais na divulgação, às vezes até em consórcio com órgãos de imprensa. Acostumamo-nos a isso de maneira equivocada. O Judiciário, que autoriza as escutas, tem responsabilidade por isso. ${ }^{7}$

De se observar que o Ministro Gilmar Mendes já externava incômodo não apenas com a questão do prazo de duração das medidas, mas também com a divulgação dos conteúdos das conversas interceptadas feita pelos agentes policiais junto aos órgão de imprensa antes mesmo de chegar ao conhecimento do juiz, muito embora não tenha proferido decisão no sentido de limitar temporalmente o prazo de duração ou a quantidade admitia de prorrogações.

Foi a própria Revista Veja (em edição de 3 de setembro de 2008), a qual o Ministro Gilmar Mendes havia concedido a citada entrevista, que divulgou o conteúdo de uma conversa telefônica havida entre o próprio Ministro e o então Senador Demóstenes Torres e acrescentou que a Abin o estava monitorando juntamente com a Polícia Federal para investigar as circunstâncias nas quais o Ministro Gilmar Mendes havia concedido liberdade ao banqueiro Daniel Dantas, pois, segundo a referida revista, "a Polícia Federal e a Abin interpretaram a decisão como uma confirmação de que alguma coisa errada se passava no gabinete do ministro...". 8

Tendo essa reportagem sido publicada em 03 de setembro de 2008, surgiu 17 (dezessete) dias depois, quando do já mencionado julgamento do recebimento da denúncia no Inq 2424 (“Operação Furacão") em 20 de setembro de 2008, a oportunidade para que o Ministro Gilmar Mendes se pronunciasse sobre as interceptações telefônicas. Nesse contexto fático e político, torna-se mais claro não apenas o porquê do Ministro ter deixado aberta a possibilidade de rever sua posição sobre o período máximo de duração da medida, mas, sobretudo, sua posição contra os agentes policiais que de fato realizam a interceptação, chamando-os de "hermeneutas dos grampos":

As histórias sobre esse tema são de todos conhecidas. De fato, hoje verificamos
certa disfuncionalidade no modelo...
Hoje, então estamos diante de situações bastante delicadas, espacialmente diante dos
abusos noticiados e cometidos. Recentemente, em uma visita a São Paulo, Senhores
Ministros, eu conversava com uma, talvez, das mais importantes editoras de jornais

7 Disponível em http://www.conjur.com.br/2008-abr-19/ministro_gilmar_mendes_entrevista_veja?pagina=3. Acessado em 22.01.2016.

8 Disponível em $\quad<\quad$ http://www.migalhas.com.br/Quentes/17,MI68048,11049Revista+Veja+A+Abin+gravou+o+ministro+Gilmar+Mendes>. Acessado em 22.01.2016. 
do Brasil, que fora atingida, numa dessas operações, porque teria aceito um encontro, um almoço, um jantar, com uma das pessoas investigadas. Essa pessoa, aparentemente, buscava no jornal uma retratação por uma notícia publicada, por isso, tentava, então marcar um almoço, e mandaram entregar um envelope. Esse envelope virou conteúdo de propina - porque, claro, nós temos, aí, os hermeneutas dos grampos. Então, essa é uma seara em que temos abusos de toda índole.

(...)

Quase exagero ao dizer que uma Corte como esta cumpre uma função muito mais importante - e essa função não é perceptível -, não pelo que ela faz - e ela faz muito, como temos demonstrado aqui, ao longo do tempo -, mas pelo que ela evita que se faça. Quando ela inibe que, desde o primeiro grau, desde o agente policial, o gendarme tentado a virar ditador comece a dar devaneios aos seus sonhos. É exatamente isso que temos que fazer neste tipo de matéria. ${ }^{9}$ (sem grifo no original)

O objeto do presente trabalho é precisamente perquirir a legitimidade para realizar a interpretação das conversas gravadas durante uma medida de interceptação telefônica judicialmente autorizada na forma da Lei $\mathrm{n}^{\mathrm{o}}$ 9.296/96.

Os problemas a serem aqui tratados são: a autoridade ou os agentes policiais estão legitimados a realizar interpretações sobre as conversas gravadas durante uma medida de interceptação telefônica que executaram por ordem judicial? Quais os efeitos de eventuais interpretações? Há vedação no ordenamento a um tal procedimento?

A hipótese considerada é que somente o juiz está autorizado a interpretar os fatos, não havendo qualquer validade em atos dessa natureza praticados pela autoridade ou pelos agentes policiais, os quais sequer devem ser admitidos aos autos do processo.

Para tanto se realizou uma pesquisa bibliográfica de natureza descritiva e explicativa sobre a natureza da prova no processo penal e sua relação com a verdade e, com base em análise qualitativa dos princípios informadores e dispositivos legais aplicáveis, verificar a hipótese de manipulação da formação da convicção judicial como um elemento nulificador dos atos praticados por juiz cuja imparcialidade tenha sido comprometida.

\section{QUESTÕES TERMINOLÓGICAS RELATIVAS À PROVA E APLICADAS ì INTERCEPTAÇÃO DAS COMUNICAÇÕES TELEFÔNICAS}

Ponto fundamental à compreensão do problema diz respeito à compreensão terminológica referente ao tema probatório.

Sabe-se que o termo prova é usado de forma indiscriminada para designar uma variada gama de significados, daí a sua natureza polissêmica tanto no trato comum, como no discurso jurídico.

\footnotetext{
${ }^{9}$ Disponível em < http://redir.stf.jus.br/paginadorpub/paginador.jsp?docTP=AC\&docID=609608>. Acessado em 22.01.2016.
} 
Entretanto, faz-se necessário realizar algumas distinções para efetiva compreensão da proposta de pesquisa realizada neste trabalho. A primeira distinção diz respeito à compreensão do que vem a ser elemento de prova e resultado da prova.

Elementos de prova, no inglês evidence, são os “...dados objetivos que confirmam ou negam uma asserção a respeito de um fato que interessa à causa”"10 e sobre os quais o juiz vai realizar um procedimento inferencial para chegar a alguma conclusão sobre os fatos. Já o resultado da prova, no inglês proof, é a própria conclusão que o julgador extrai dos diversos elementos de prova existentes, por meio de um procedimento intelectual para estabelecer a veracidade ou não dos fatos alegados. Estes fatos alegados são chamados de objeto de prova.

Há que se distinguir, ainda, fonte de prova, meio de prova e meio de obtenção ou investigação de prova.

Fonte de prova são as pessoas ou coisas que podem fornecer uma informação apreciável sobre o objeto de prova, ou seja, os fatos alegados. Daí porque as fonte podem ser reais (documentos lato sensu) ou pessoais (testemunhas, acusado, vítima, perito, assistentes técnicos).

Meios de prova são instrumentos ou atividades endoprocessuais que se desenvolvem perante o juiz, com conhecimento e participação das partes, pelos quais as fontes de prova introduzem elementos de prova no processo. Diferenciam-se dos meios de investigação de prova, também chamados meios de pesquisa da prova ou meios de obtenção de prova, que são atividades extraprocessuais, que podem ser produzidos na fase investigatória, sem a participação do investigado, baseado no fator "surpresa"

Nosso Código de Processo Penal não distingue entre meios de prova e meios de investigação de prova. O Codice di Procedura Penale ${ }^{12}$ italiano distingue no Livro III, Titulo II os meios de prova (testemunhal, confronto ou acareação, reconhecimento, reprodução judicial, pericial e documental) e no Título III os meios de pesquisa da prova (inspeções, buscas, sequestros e interceptações das conversas ou comunicações).

A interceptação das comunicações telefônicas no Brasil, que como já visto está regulada pela Lei $n^{\circ} 9.296$ de 1996, constitui um meio de investigação ou de obtenção ou de

\footnotetext{
${ }^{10}$ GOMES FILHO, Antonio Magalhães. "Notas sobre a terminologia da prova (reflexos no processo penal brasileiro)" In YARSHELL, Flávio Luiz e ZANOIDE DE MORAES, Maurício. Estudos em homenagem à Professora Ada Pellegrini Grinover. São Paulo: DPJ Editora, 2005, p. 307.

${ }^{11}$ TONINI, Paolo. A prova no processo penal italiano. Tradução Alexandra Martins e Daniela Mróz. São Paulo: Revista dos Tribunais, 2002, p. 242.

12 Disponível em <http://www.polpenuil.it/attachments/048_codice_di_procedura_penale.pdf>. Acesso em 25. mar.2015.
} 
pesquisa da prova, cuja aptidão para levar ao processo elementos probatórios deve ser analisada de maneira cuidadosa.

\section{O CONTRADITÓRIO NA INTERCEPTAÇÃO TELEFÔNICA OU A FALTA DELE}

É muito comum tratar o direito ao contraditório no processo penal apenas no que respeita ao aspecto argumentativo, como a possibilidade de falar sobre o que for aduzido pela parte oposta. Porém essa é uma visão simplista que ignora dever o contraditório ir muito além da aparência formal para se consubstanciar em poder de informação, força de confronto e paridade de armas.

O exercício pleno desse direito no processo penal deve passar por seis momentos: (1) a oportunidade de postular a prova em igualdade de oportunidades e condições; (2) a possibilidade de impugnar a prova postulada pela parte adversa; (3) a possibilidade de impugnar a decisão que admite a prova; (4) a participação e assistência na produção da prova; (5) a possibilidade aportar considerações sobre a validade do elemento gerado e razões para influenciar o magistrado na valoração dos elementos válidos antes que se convertam em resultados probatórios; (6) a possibilidade de controlar a racionalidade da decisão do julgador pela impugnação dos fundamentos por via recursal.

Assim se conclui que o contraditório é um direito constitucionalmente assegurado, que concede às partes de um processo judicial a faculdade de tomar conhecimento (informação) e de discutir todos os elementos apresentados ao julgador (poder de reação) em igualdade de condições (paridade de armas) com a finalidade de influenciar sua decisão (poder de influência), que é responsável por torná-lo eficaz, e controlar sua racionalidade (direito ao recurso).

Em outras palavras, o contraditório se torna palpável na expressão do poder de influência que a parte é capaz de exercer sobre a formação cognitiva do juiz, fazendo entender que além de apresentar os elementos obrigatórios, formais (ou aparentes) e materiais (ou substanciais), o contraditório precisa se mostrar eficaz.

Contudo, o legislador no artigo $155^{13}$ do Código de Processo Penal (CPP) aparentemente trouxe uma exceção à exigência do contraditório judicial, relegando a um segundo plano o princípio do contraditório em prol da expansão de possibilidades de investigação. Essa opção legislativa obedece a uma lógica inquisitória intrínseca ao Código de

\footnotetext{
${ }^{13}$ Art. 155, CPP: "O juiz formará sua convicção pela livre apreciação da prova produzida em contraditório judicial, não podendo fundamentar sua decisão exclusivamente nos elementos informativos colhidos na investigação, ressalvadas as provas cautelares, não repetíveis e antecipadas."
} 
Processo Penal, que muito já se modificou com a reforma acontecida em 2008, mas deixou neste artigo seus resquícios.

Todavia, numa leitura processual-constitucional, é inconcebível que uma escolha de política criminal possa preterir um princípio constitucional, ponto em que a doutrina converge com os tribunais superiores, reconhecendo como indispensável o contraditório, sob pena de nulidade do processo.

Desse entendimento nasceu o contraditório diferido, que consiste no exercício do contraditório extemporâneo à obtenção da prova, na tentativa de salvar a utilização de provas cautelares, não repetíveis e antecipadas.

O comportamento de muitos doutrinadores - que cunharam os termos "contraditório diferido", "contraditório postergado" e "contraditório retardado" - e dos tribunais indica que essa versão do contraditório tem sido amplamente aceita. Exemplo disso é a decisão do Supremo Tribunal Federal abaixo colacionada.

O inquérito não possui contraditório, mas as medidas invasivas deferidas judicialmente devem se submeter a esse princípio [do contraditório], e a sua subtração acarreta nulidade. Obviamente não é possível falar-se em contraditório absoluto quando se trata de medidas invasivas e redutoras da privacidade. Ao investigado não é dado conhecer previamente - sequer de forma concomitante - os fundamentos da medida que lhe restringe a privacidade. Intimar o investigado da decisão de quebra de sigilo telefônico tornaria inócua a decisão. Contudo, isso não significa a ineficácia do princípio do contraditório. Com efeito, cessada a medida, e reunidas as provas colhidas por esse meio, o investigado deve ter acesso ao que foi produzido, nos termos da Súmula Vinculante $\mathrm{n}^{\circ}$ 14. Os fundamentos da decisão que deferiu a escuta telefônica, além das decisões posteriores que mantiveram o monitoramento devem estar acessíveis à parte investigada no momento de análise da denúncia e não podem ser subtraídas da Corte, que se vê tolhida na sua função de apreciar a existência de justa causa da ação penal. Trata-se de um contraditório diferido, que permite ao cidadão exercer um controle sobre as invasões de privacidade operadas pelo Estado. ${ }^{14}$

Entretanto, apesar da conveniência da aplicação desta pretensa modalidade de contraditório, doutrinadores mais críticos caminham no sentido de refutar esse entendimento, como Giulio Ubertis, para quem, se faltar algum dos elementos essenciais do contraditório, estaremos diante de um contraditório impossível. O próprio Ubertis ${ }^{15}$ usa o caso da

\footnotetext{
${ }^{14}$ SUPREMO TRIBUNAL FEDERAL. INQUÉRITO No 2.266/AMAPÁ. RELATOR MINISTRO GILMAR MENDES. TRIBUNAL PLENO. Julgamento em 26.5.2011, DJe de 13.3.2012. Disponível em: <http://redir.stf.jus.br/paginadorpub/paginador.jsp?docTP=TP\&docID=1812853>. Acessado em 10/02/2015.

15 "Quanto al contraddittorio impossibile, esso andrebbe rigorosamente inteso come legittimante l'impiego processuale di strumenti gnoseologici dei quali sia "accertata" (cioè indubbia, sicura, innegabile; quindi, non soltanto presunta o convenzionamente stabilita dal legislatore) l'inconciliabilità con il contraddittorio perché intrinsecamente incompatibili con quest'ultimo (come avviene per le intercettazione di comunicazioni, la cui attendibilità sarebbe inevitabilmente compromessa da un preavviso de loro comprimento alla persona
} 
interceptação de comunicações como exemplo, uma vez que um aviso de seu cumprimento à pessoa sob investigação não é possível por motivos óbvios, fazendo faltar o elemento informação/conhecimento intrínseco ao exercício pleno do contraditório.

Ora, como seria concebível um contraditório verdadeiro exercido a posteriori diante dos já citados fatores de composição inegociáveis desse direito, a saber: acesso irrestrito às informações pertinentes ao caso, instrumentos de insurgência contra a pretensão acusatória, paridade de armas e, em especial, poder de influência na decisão judicial? O que está por trás dessa prática que se instaurou no processo penal brasileiro?

A facilitação a que as agências de persecução introduzam elementos para formação do convencimento do juiz no processo penal é, naturalmente, o principal objetivo.

Ocorre que sua utilização indiscriminada denota certa ideologia repressiva, tendente a fazer prevalecer no embate axiológico à defesa social sobre a liberdade. Sobre esse tema, Geraldo Prado escreveu:

\footnotetext{
Em um cenário de tensão entre liberdade e segurança e sob a inspiração da retórica do risco, os Estados produzem normativas que acossam os direitos fundamentais visando ampliar os recursos à disposição da repressão penal.

As pesquisas policias são incrementadas com o emprego de métodos ocultos de investigação autorizados judicialmente, como a interceptação telefônica e de emails, as escutas domiciliares e a infiltração de agentes, convertendo-se a prática em modelo de atuação preliminar. ${ }^{16}$
}

Muitos são os prejuízos desse proceder, desde a contaminação das provas até a drástica redução da possibilidade de defesa pela restrição de informações.

Todavia, uma questão sobre a qual doutrina e jurisprudência dificilmente se debruçam é o comprometimento cognitivo do julgador que teve contato unilateralmente com a acusação (e sua tese) a fim de decidir sobre a autorização da cautelar, ficando prevento para julgar a causa. Neste caso o contraditório diferido termina por servir apenas para legitimar a prova unilateral, na medida em que a cognição do julgador já se formou pelo contato inicial com as informações, de tal sorte que novos conjuntos de elementos cognitivos acabam por se submeter a procedimentos psicológicos de afastamento ou redução da dissonância cognitiva com a prevalência dos elementos conhecidos previamente ${ }^{17}$.

sottoposta alle indagini) oppure perché recanti elementi di prova contenustiticamente o strutturalmente diversi da quelli che sarebbero generabili esso (...)." UBERTIS, Giulio. op. cit., p. 338.

${ }^{16}$ PRADO, Geraldo. "Prova penal e sistema de controles epistêmicos: a quebra da cadeia de custódia das provas obtidas por métodos ocultos”. $1^{\text {a }}$ ed. São Paulo: Marcial Pons, 2014, p. 59.

${ }_{17}$ Nesse sentido vale a leitura de FESTINGER, Leon. Teoria da dissonância cognitiva. Tradução Eduardo Almeida. Rio de Janeiro: Zahar editores, 1975. Sobre a influência que os elementos cognitivos da investigação exercem sobre a formação da convicção judicial SCHÜNEMANN, Bernd. O juiz como um terceiro manipulado 
Esse é o típico caso da interceptação telefônica, na qual esse contato prévio com as informações provavelmente se repetirá com a prorrogação (ou as prorrogações) do tempo de escuta, que dependem de decisão fundamentada ${ }^{18}$, ou seja, o magistrado disporá sobre os motivos que o levaram ao convencimento de que os indícios apresentados são suficientes para suspeitar do investigado, denotando já haver uma aproximação da cognição do julgador com a tese (ou futura tese) acusatória.

Tal fenômeno foi descrito por Paulo Biskup de Aquino como a transformação de meros indícios em elementos definidores da figura delitiva. Ele explica que “...cada vez mais se utiliza fatores indiciários para incriminar sujeitos, principalmente para a decretação de medidas cautelares em busca de provas, como é o caso da interceptação telefônica e a lei do crime organizado". ${ }^{19}$

Porém o problema mais desafiador gerado pela prova produzida cautelarmente decorre dos casos em que o sigilo é indissociável do procedimento de obtenção do conteúdo da informação, como ocorre na interceptação e também na infiltração de agentes. Em situações como essas, de provas ocultas ${ }^{20}$, é possível identificar implicações que tornam atualmente impraticável o pleno exercício do contraditório.

Basicamente, no caso das provas cautelares em geral, o exercício do contraditório deveria se dar ainda na fase investigatória com uma rigorosa cadeia de custódia do material probatório, como pensada por Prado ${ }^{21}$, e a prevenção negativa do julgador - como previsto, e.g., nas legislações francesa ${ }^{22}$ e portuguesa ${ }^{23}$, onde existe a figura do juiz de instrução - se

no processo penal? Uma confirmação empírica dos efeitos perseverança e aliança in Estudos de direito penal, direito processual penal e filosofia do direito. Tradução Luís Greco. São Paulo: Marcial Pons, 2013.

${ }^{18}$ Art. 50, lei 9.296/96: “A decisão será fundamentada, sob pena de nulidade, indicando também a forma de execução da diligência, que não poderá exceder o prazo de quinze dias, renovável por igual tempo uma vez comprovada a indispensabilidade do meio de prova. ". (grifo nosso)

19 AQUINO, Paulo Biskup de., ROLAND, Claudia Symone Dias. "As interceptações telefônicas e o processo penal brasileiro: uma reflexão". $1^{a}$ ed. Curitiba: Editora Prismas, 2015, p. 63-64.

${ }^{20}$ PRADO. op. cit., p. 59 e ss.

21 "No direito brasileiro praticamente não há referências doutrinárias à cadeia de custódia, designação pela qual é conhecido o dispositivo que pretende assegurar a integridade dos elementos probatórios, não obstante o seu significado em termos de redução de complexidade de garantia constitucional contra a prova ilícita." PRADO, Geraldo. op. cit., p. 80.

${ }^{22}$ Article 100-3, Códe de Procédure Pénale: "Le juge d'instruction ou l'officier de police judiciaire commis par lui peut requérir tout agent qualifié d'un service ou organisme placé sous l'autorité ou la tutelle du ministre chargé des télécommunications ou tout agent qualifié d'un exploitant de réseau ou fournisseur de services de télécommunications autorisé, en vue de procéder à l'installation d'un dispositif d'interception. ”

${ }^{23}$ Artigo 187, Código de Processo Penal português: "1 - A intercepção e a gravação de conversações ou comunicações telefónicas só podem ser autorizadas durante o inquérito, se houver razões para crer que a diligência é indispensável para a descoberta da verdade ou que a prova seria, de outra forma, impossível ou muito difícil de obter, por despacho fundamentado do juiz de instrução e mediante requerimento do Ministério Público, quanto a crimes:

a) Puníveis com pena de prisão superior, no seu máximo, a 3 anos;

b) Relativos ao tráfico de estupefacientes; 
apresentam em conjunto como possível solução, que é acompanhada da possibilidade de a defesa exercer atos de investigação ${ }^{24}$ tais quais os praticados pela polícia e pelo Ministério Público, conferindo equidistância às partes.

Contudo, quando se trata da interceptação das comunicações telefônicas, devido ao segredo que lhe é imanente, nenhuma dessas propostas parece apta a salvar a essência do contraditório, que resta perdida pela impossibilidade de igualdade de acesso a informação e de contra-argumentação gerados pela quebra de paridade, culminando também em perda de força de influência no convencimento do juiz.

Pontue-se que, pela essência da interceptação das comunicações telefônicas, não é dado às partes, em igualdade de condições, as oportunidades para: (1) postular a prova; (2) discutir a admissão da prova antes da decisão que o faz e (3) participar da produção da prova.

\section{CONCLUSÃO - O PROCESSO COMO MODELO EPISTEMOLÓGICO DE CONHECIMENTO CONDICIONANTE DA VALIDADE DA DECISÃO}

A formação do convencimento judicial não pode se dar ao arrepio da verdade. Entretanto, não esta se adotando um conceito de verdade como equivalência, pois que cada parte constrói sua narrativa sobre os fatos e a narrativa construída pelo juiz deve ser completa e coerente para que seja reputada racional.

Luigi Ferrajoli esclarece que tanto do ponto de vista epistemológico, como político, como jurídico, o que se exige é "que a legitimidade das decisões penais se condicione à verdade empírica de suas motivações" ${ }^{25}$. Todavia, essa racionalidade é obtida a posteriori da efetiva formação da convicção judicial, pois que verificada pela motivação exposta.

c) De detenção de arma proibida e de tráfico de armas;

d) De contrabando;

e) De injúria, de ameaça, de coacção, de devassa da vida privada e perturbação da paz e do sossego, quando cometidos através de telefone;

f) De ameaça com prática de crime ou de abuso e simulação de sinais de perigo; ou

g) De evasão, quando o arguido haja sido condenado por algum dos crimes previstos nas alíneas anteriores."

${ }^{24}$ A reforma sofrida pelo sistema processual italiano é um exemplo interessante sobre a necessidade de, em sistema acusatório, permitir-se, ao lado da investigação estatal, outra realizada pela defesa. SCARANCE FERNANDES, Antonio. "O Equilíbrio na Investigação Criminal” in YARSHELL, Flávio Luis; MORAES, Maurício Zanoide (org.). Estudos em homenagem à professora Ada Pellegrini Grinover. São Paulo: DPJ, 2005, p. 327.

${ }^{25}$ FERRAJOLI, Luigi. Direito e razão: teoria do garantismo penal 4a ed. Tradutores Ana Paula Zomer Sica, Fauzi Hassan Choukr, Juarez Tavares e Luiz Flávio Gomes. São Paulo: Revista dos Tribunais, 2014, p. 70. 
O processo, segundo Michele Taruffo, sob uma perspectiva metodológica, pode ser analisado “como um 'modelo epistemológico' do conhecimento dos fatos com base nas provas, 26 . E ressalta:

Em todo e qualquer procedimento de caráter epistêmico tem importância decisiva o método, ou seja, o conjunto das modalidades com que são selecionadas, controladas e utilizadas as informações que servem para demonstrar a veracidade das conclusões. No âmbito do processo isso equivale a fazer referência sobretudo às regras que disciplinam a produção das provas e sua utilização, ou seja, ao "direito das provas" e à equivalente noção anglo-americana da law of evidence. ${ }^{27}$

Portanto, resta claro que o processo penal se legitima pela busca do conhecimento da verdade com base nas provas. Certo de que os fatos estão no passado, as provas nada mais são do que signos transmitidos, são materiais semióticos que representam a única via de acesso ao conhecimento $^{28}$ e que, como em todo procedimento de caráter epistêmico, devem ser obtidas com estrita observância do método de produção e utilização.

Há, portanto, que se definir se a interceptação das comunicações telefônicas é um meio de investigação de prova típico ou atípico. Neste ponto é importante pontuar que meios típicos não se caracterizam meramente por estarem previstos em lei, pois, como pontua Scarance, apoiado na lição de Antonio Laronga, "a prova típica é aquela prevista e dotada de procedimento próprio para sua efetivação; a prova atípica, por conseguinte, é aquela que, prevista ou não, é destituída de procedimento para sua produção."29

Nesse sentido seriam típicos aqueles cuja previsão e procedimento estão regulamentadas, seja o procedimento próprio ou por remissão. De outro lado, não estando previsto o meio ou, ainda que previsto, se o procedimento não está regulamentado ou é objeto de remissão, está-se diante de um meio atípico.

Ora, o art. $5^{\circ}$ da Lei $n^{\circ} 9.296$ de 1996 prevê não apenas que a decisão que defere a medida deve ser fundamentada, mas que o juiz deve indicar "a forma de execução da diligência", omitindo-se na regulamentação do procedimento aplicável.

Ademais, o $\$ 2^{\circ}$ do art. $6^{\circ}$ da mesma Lei determina que "cumprida a diligência, a autoridade policial encaminhará o resultado da interceptação ao juiz, acompanhado de auto

\footnotetext{
${ }^{26}$ TARUFFO, Michele. Uma simples verdade: o juiz e a construção dos fatos. Tradução Vitor de Paula Ramos. São Paulo: Marcial Pons, 2012, p. 160.

${ }^{27}$ Ibid, p. 164.

${ }^{28}$ ANDRÉS IBÁÑEZ, Perfecto. Prueba y convicción judicial en el proceso penal. Buenos Aires: Hammurabi, 2009 , p 49.

${ }^{29}$ SCARANCE FERNANDES, Antonio. "Tipicidade e sucedâneos de prova" in: SCARANCE FERNANDES, Antonio, GAVIÃO DE ALMEIDA, José Raul e ZANOIDE DE MORAES, Maurício (coordenadores) Provas no Processo Penal: estudo comparado. São Paulo: RT, 2012, p. 15.
} 
circunstanciado, que deverá conter o resumo das operações realizadas", mas não define o que se entende por "resultado da interceptação" e, de forma exauriente, o que deve conter "o auto circunstanciado", apenas referindo-se ao resumo das operações.

Dessa forma, como muito bem observou Geraldo Prado, quando a legislação silencia sobre o procedimento probatório, há exigência de motivação da "decisão que defere o emprego de métodos ocultos de investigação importa" ${ }^{30}$ não apenas na indicação dos elementos que convencem acerca da sua adequação, mas "ainda, na definição dos meios de sua execução e fiscalização, ${ }^{, 31}$.

Isso significa que o procedimento da interceptação das comunicações telefônicas não é regulamentado, sendo deixado ao juiz, no ato decisório, fazê-lo. Isso implica em que a interceptação das comunicações é um meio de investigação de prova atípico.

Neste ponto faremos uma observação neste trabalho de pesquisa para ressalvar nosso entendimento pessoal sobre a possibilidade de que a interceptação telefônica gere elementos de prova valoráveis pelo juiz. Compreendemos tratar-se de um sucedâneo de prova ${ }^{32}$ que é apto apenas a descobrir fontes de prova que devem se submeter ao contraditório apropriado para que forneçam elementos valoráveis ${ }^{33}$.

Todavia, a jurisprudência admite que o juiz valore os conteúdos de conversas obtidos durante as diligências de interceptação telefônica, portanto nos importa trabalhar com esse entendimento majoritário para analisar o problema da hermenêutica policial ou pré-judicial.

A falta de densidade dos elementos constantes do $\S 2^{\circ}$ do art. $6^{\circ}$ da Lei $\mathrm{n}^{\circ} 9.296 / 96$, a saber, "resultado da interceptação" e o exato conteúdo do "o auto circunstanciado" implica em que não se saiba se os chamados resultados da interceptação são as transcrições (integrais ou parciais), se são os fonogramas ou o suporte magnético que os armazena (CD, DVD, HD, etc.), tampouco se sabe o que podem a autoridade policial e seus agentes fazer constar do

\footnotetext{
${ }^{30}$ PRADO, Geraldo. op. cit., p. 78.

31 Ibid.

32 Assim compreendido o fenômeno processual que decorre de dois fatores: (1) o uso, na audiência de julgamento, como elementos probatórios de elementos colhidos em fases anteriores e (2) a substituição de um meio de prova por outro. (SCARANCE, op. cit., p. 30)

${ }^{33}$ De forma muito resumida, a interceptação das comunicações telefônicas não geram elementos de prova e todos os dados obtidos da interceptação que o juiz valora são sucedâneos de prova posto que (1) não cabe ao juiz analisar o fonograma ou as transcrições das conversas telefônicas interceptadas como se elementos de prova fossem, pois que não se deve confundir meio de obtenção de prova (a interceptação) com o suporte em que se registram os dados colhidos (documento), de sorte que tal procedimento implicaria em substituir um meio de (obtenção de) prova por outro; e (2) não cabe ao juiz usar na audiência ou mesmo na sentença o que foi colhido na fase anterior à propositura da ação penal durante a interceptação das comunicações telefônicas porque esta descobre fontes pessoais (e não reais), às quais obrigatoriamente só podem gerar dados a serem introduzidos ao processo e aptos a serem valorados (elementos de prova) se submetidos ao meio de prova oral, com seu sistema específico de exercício do contraditório (direto e cruzado), não se podendo aplicar-lhe o contraditório diferido que é próprio do meio de prova documental cujo elemento é pré-existente.
} 
"auto circunstanciado", que normalmente, na prática, é um conjunto de atos como relatórios, análises, transcrições parciais e, o pior de tudo, interpretações sobre o suposto significado das conversas ouvidas.

Essa atividade interpretativa da autoridade e dos agentes policiais cria uma disfunção no sistema de interceptações telefônicas, porquanto diante da ausência de tempo para ouvir as milhares de horas de conversas captadas pelos sistemas de tecnologia da informação, o juiz decide sobre as prorrogações com base nas informações fornecidas pela autoridade policial, que já estão previamente valoradas e, portanto, conduzem a formação da convicção judicial de forma metodologicamente mais perniciosa que a mera inexistência de contraditório direto.

Isso porque mais grave do que não ser dado ao juiz ter contato direto com a informação bruta sem a participação das partes, a prática da interceptação telefônica no Brasil, demonstra que o primeiro contato que o julgador tem é com uma narrativa da verdade construída por quem sequer é parte do processo (ou do futuro processo) e que termina por macular sua imparcialidade pelos chamados efeito aliança, segundo o qual "o comportamento do juiz pode ser explicado também simplesmente pelo fato de que, diante de uma situação obscura, ele se orienta segundo uma prévia avaliação oriunda de uma pessoa por ele aceita como competente" ${ }^{, 34}$, e efeito perseverança, qual seja, "as informações que confirmam uma hipótese que, em algum momento anterior fora considerada correta, são sistematicamente superestimadas, enquanto as informações contrárias são sistematicamente menosprezadas",35.

Neste sentido, para que o magistrado defira uma medida de interceptação telefônica, ele deve primeiramente aderir à construção narrativa da verdade de quem a requer e, com muito mais razão, deve densificar essa adesão para prorrogar sucessivamente as medidas.

Ao contrário, qualquer versão narrativa que se apresente dissonante é submetida a um mecanismo de equilíbrio do sistema cognitivo, que faça desaparecer as contradições, restaurando a consonância. Dessa forma, se o sucesso de qualquer atividade da defesa já restava maculada com a inoperância do contraditório diferido, a admissão da atividade interpretativa da autoridade policial e seus agentes implica na impossibilidade de garantir o respeito ao princípio da imparcialidade judicial, do contraditório e da ampla defesa.

Neste sentido, a inexistência de um rígido procedimento probatório para a interceptação telefônica, implica na necessidade de compatibilizá-la aos princípios constitucionais que norteiam o processo, de tal sorte que a omissão legislativa sobre a

\footnotetext{
${ }^{34}$ SCHUNEMANN. Op. cit., p. 213.

${ }^{35}$ Id. p. 208.
} 
possibilidade de que os agentes executores da medida interpretem seu conteúdo significa na sua proibição.

O processo é um modelo epistemológico de conhecimento cuja não observância macula a livre formação do convencimento e a existência de fundamentação da decisão não elide a vulneração dos direitos fundamentais, em especial a necessária imparcialidade.

A atividade valorativa dos "hermeneutas dos grampos" invalida a decisão judicial proferida com base na interceptação telefônica prejudicialmente interpretada.

\section{REFERÊNCIAS}

ABEL LLUCH, Xavier e RICHARD GONZÁLEZ, Manuel. Estudios sobre prueba penal volumen III: Actos de investigación y medios de prueba en el proceso penal: diligencias de instrucción, entrada y registro, intervención de comunicaciones, valoración y revisión de la prueba en vía de recurso. Madri: La Ley Actualidad, 2013.

AGUILAR, Francisco. Dos Conhecimentos Fortuitos Obtidos Através de Escutas Telefónicas. Coimbra: Almedina, 2004.

AQUINO, Paulo Biskup de., ROLAND, Claudia Symone Dias. “As interceptações telefônicas e o processo penal brasileiro: uma reflexão". $1^{\mathrm{a}}$ ed. Curitiba: Editora Prismas, 2015.

ANDRÉS IBÁÑEZ, Perfecto. Prueba y convicción judicial en el proceso penal. Buenos Aires: Hammurabi, 2009.

BACIGALUPO, Enrique. El debido proceso penal. Buenos Aires: Hammurabi, 2007.

CONTI, Carlotta e TONINI, Paolo. Il diritto delle prove penali. Milão: Giuffrè, 2012.

COSTA ANDRADE, Manuel da. Sobre as Proibições de prova em processo penal. Coimbra: Coimbra, 2006.

FERRAJOLI, Luigi. Direito e razão: teoria do garantismo penal 4a ed. Tradutores Ana Paula Zomer Sica, Fauzi Hassan Choukr, Juarez Tavares e Luiz Flávio Gomes. São Paulo: Revista dos Tribunais, 2014.

FESTINGER, Leon. Teoria da dissonância cognitiva. Tradução Eduardo Almeida. Rio de Janeiro: Zahar editores, 1975.

GOMES, Luiz Flávio e MACIEL, Silvio. Interceptação Telefônica: Comentários à Lei 9.296, de 24.07.1996. $3^{\mathrm{a}}$ edição. São Paulo: RT, 2014.

GOMES FILHO, Antonio Magalhães. "Notas sobre a terminologia da prova (reflexos no processo penal brasileiro)" In YARSHELL, Flávio Luiz e ZANOIDE DE MORAES, Maurício. Estudos em homenagem à Professora Ada Pellegrini Grinover. São Paulo: DPJ Editora, 2005.

. A motivacão das decisões penais. 2a edição. São Paulo: RT, 2013.

GÖSSEL, Karl Heinz. El derecho procesal penal en el Estado de Derecho. Obras completas. Tomo I. Santa Fe: Rubinzal-Culzoni, 2007.

GRINOVER, Ada Pellegrini. Provas Ilícitas, Interceptações e Escutas. 1 a edição. Brasília: Gazeta Jurídica, 2013.

GUERRERO PALOMARES, Salvador. La Imparcialidad Objetiva del Juez Penal: Análisis jurisprudencial y valoración crítica. Pamplona: Aranzadi, 2009. 
MARTINS, Rui Cunha. O ponto cego do direito: the brazilian lessons. $3^{\text {a }}$ ed. São Paulo: Atlas, 2013.

O mapeamento procesual da “verdade”. In: “Decisão Judicial”. São Paulo: Marcial Pons, 2013.

MAYA, André Machado. Imparcialidade e proceso penal: da prevençào da competencia ao juiz das garantías. Rio de Janeiro: Lumen Juris, 2011.

MUÑOZ CONDE, Francisco. De las prohibiciones probatorias al derecho procesal penal del enemigo. Buenos Aires: Hammurabi, 2008.

. Valoración de las grabaciones audiovisuales en el proceso penal. 2a ed. Buenos Aires: Hammurabi, 2007.

. La búsqueda de la verdade en el processo penal. $3^{\text {a }}$ edição. Buenos Aires: Hammurabi, 2007.

NIEVA FENOLL, Jordi. La duda en el proceso penal. Barcelona: Marcial Pons, 2013.

. La valoración de la prueba. Barcelona: Marcial Pons, 2010.

PRADO, Geraldo. Prova penal e sistema de controles epistêmicos: a quebra da cadeia de custódia das provas obtidas por métodos ocultos. São Paulo: Marcial Pons, 2014.

RODRIGUES, Benjamim Silva. A monitorização dos fluxos inormacionais e comunicacionais. Volume I. Coimbra: Coimbra, 2009.

ROSA, Gabriela Porto. A construção da verdade no processo penal. Rio de Janeiro: Lumen Juris, 2015.

ROXIN, Claus. La prohibición de autoincriminación y de las escuchas domiciliarias. Buenos Aires: Hammurabi, 2008.

SCARANCE FERNANDES, Antonio. "O Equilíbrio na Investigação Criminal” in YARSHELL, Flávio Luis; MORAES, Maurício Zanoide (org.). Estudos em homenagem à professora Ada Pellegrini Grinover. São Paulo: DPJ, 2005.

."Tipicidade e sucedâneos de prova” in: SCARANCE FERNANDES, Antonio, GAVIÃO DE ALMEIDA, José Raul e ZANOIDE DE MORAES, Maurício (coordenadores) Provas no Processo Penal: estudo comparado. São Paulo: RT, 2012, p. 15.

SCHÜNEMANN, Bernd. O juiz como um terceiro manipulado no processo penal? Uma confirmação empírica dos efeitos perseverança e aliança in Estudos de direito penal, direito processual penal e filosofia do direito. Tradução Luís Greco. São Paulo: Marcial Pons, 2013.

STRECK, Lenio Luiz. Verdade e Consenso: Constituição, Hermenêutica e Teorias Discursivas. $4^{\mathrm{a}}$ ed. São Paulo: Saraivva, 2012.

TARUFFO, Michele. Uma simples verdade: o juiz e a construção dos fatos. Tradução Vitor de Paula Ramos. São Paulo: Marcial Pons, 2012.

TONINI, Paolo. A prova no processo penal italiano. Tradução Alexandra Martins e Daniela Mróz. São Paulo: Revista dos Tribunais, 2002.

UBERTIS, Giulio. "Il contradittorio nella formazione dela prova penale.” In YARSHELL, Flávio Luiz e ZANOIDE DE MORAES, Maurício. Estudos em homenagem à Professora Ada Pellegrini Grinover. São Paulo: DPJ Editora, 2005.

VALENTE, Manuel Monteiro Guedes. Escutas Telefónicas: da excepcionalidade à vulgaridade. $2^{\mathrm{a}}$ ed. Coimbra: Almedina, 2008. 